\title{
Asymmetric Total Synthesis of Rollicosin
}

Kevin J. Quinn,* André K. Isaacs, Brian A. DeChristopher, Stephanie C. Szklarz, and Rebecca A. Arvary

Department of Chemistry, College of the Holy Cross, Worcester, MA 01610-2395

\section{SUPPORTING INFORMATION}

General. Unless otherwise noted, all non-aqueous reactions were performed in flame-dried glassware under nitrogen. Optical rotations were measured on a Perkin Elmer 341 polarimeter at room temperature. Concentrations (c) are reported in $\mathrm{g} / 100 \mathrm{~mL}$. Infrared spectra (IR) were obtained on a Perkin Elmer 1600 Series FT-IR. Proton nuclear magnetic resonance $\left({ }^{1} \mathbf{H}\right.$ NMR) spectra and carbon nuclear magnetic resonance $\left({ }^{13} \mathbf{C}\right.$ NMR) spectra and were recorded on a Varian Inova-400 at $400 \mathrm{MHz}$ and $100 \mathrm{MHz}$ respectively. Chemical shifts are reported in ppm relative to $\mathrm{CHCl}_{3}\left(\delta\right.$ 7.27) for ${ }^{1} \mathrm{H}$ NMR and the central resonance of $\mathrm{CDCl}_{3}(\delta 77.0)$ for ${ }^{13} \mathrm{C} \mathrm{NMR}$. High resolution fast atom bombardment mass spectra (HRMS) were obtained on a JEOL MStation JMS-700 mass spectrometer at the University of Massachusetts-Amherst.

EM Science DriSolv ${ }^{\circledast}$ solvents $\left(\mathrm{CH}_{2} \mathrm{Cl}_{2}, \mathrm{PhH}, \mathrm{THF}, \mathrm{PhCH}_{3}\right)$ were used in moisture sensitive reactions. $(R, R)$-hexa-1,5-diene-3,4-diol 10 was prepared from D-mannitol using the protocol reported by Burke and Sametz. ${ }^{1}$ Benzyl ether 8 was prepared from 10-undecen-1ol as described by Chow and Kitching. ${ }^{2}$ (5S)-Methyl-3phenylsulfanyldihydrofuran-2-one $\mathbf{3}$ was prepared according to the procedure of White, Somers, and Reddy. ${ }^{3}$ Commercially available reagents and solvents were used as received without further purification.

\section{Experimental Procedures.}

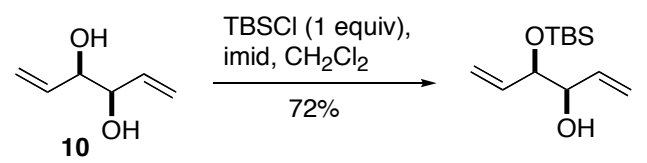

Mono-TBS Ether of 10. To a solution of $(R, R)$-hexa-1,5-diene-3,4-diol 10 (3.075 g, 26.94 mmol) in $\mathrm{CH}_{2} \mathrm{Cl}_{2}$ (135 $\mathrm{mL})$ at $0{ }^{\circ} \mathrm{C}$ was added imidazole $(2.752 \mathrm{~g}, 40.41 \mathrm{mmol})$ and $\mathrm{TBSCl}(4.060 \mathrm{~g}, 26.94 \mathrm{mmol})$. The reaction mixture was allowed to warm to room temperature and stirred for $18 \mathrm{~h}$, after which time it was quenched by addition of $\mathrm{H}_{2} \mathrm{O}$ $(100 \mathrm{~mL})$. The biphasic mixture was diluted with $\mathrm{Et}_{2} \mathrm{O}(200 \mathrm{~mL})$ and transferred to a separatory funnel. The layers were separated, and the aqueous phase was extracted with $\mathrm{Et}_{2} \mathrm{O}(3 \times 150 \mathrm{~mL})$. The combined organic phases were washed with $0.1 \mathrm{M} \mathrm{HCl}(150 \mathrm{~mL})$ and brine $(150 \mathrm{~mL})$ and dried over $\mathrm{MgSO}_{4}$. The drying agent was removed by filtration, and solvents were removed in vacuo. Purification by silica gel chromatography $\left(6: 1\right.$ pentane/ $\left./ \mathrm{Et}_{2} \mathrm{O}\right)$ provided $4.430 \mathrm{~g}(72 \%)$ of the corresponding mono-TBS ether as a colorless oil. Data for the mono-TBS ether of 10: $[\alpha]_{\mathrm{D}}^{22}+80.1\left(c\right.$ 2.21, $\left.\mathrm{CH}_{2} \mathrm{Cl}_{2}\right)$; IR (thin film) 3567, 3054, 2956, 2931, 2886, $2858 \mathrm{~cm}^{-1} ;{ }^{1} \mathbf{H} \mathbf{N M R}\left(\mathrm{CDCl}_{3}, 400\right.$ MHz) $\delta 5.85(\mathrm{ddd}, J=17.2,10.5,5.3 \mathrm{~Hz}, 1 \mathrm{H}), 5.82(\mathrm{ddd}, J=17.2,10.4,6.4 \mathrm{~Hz}, 1 \mathrm{H}), 5.34(\mathrm{dt}, J=17.2,1.6 \mathrm{~Hz}$, 1H), 5.25 (ddd, $J=17.2,1.6,1.2 \mathrm{~Hz}, 1 \mathrm{H}), 5.22(\mathrm{~m}, 1 \mathrm{H}), 5.19(\mathrm{~m}, 1 \mathrm{H}), 4.00-3.93(\mathrm{~m}, 2 \mathrm{H}), 2.54(\mathrm{br} \mathrm{s}, 1 \mathrm{H}), 0.92(\mathrm{~s}$, 
9H), 0.09 (s, 3H), 0.06 (s, 3H); ${ }^{13} \mathbf{C}$ NMR $\left(\mathrm{CDCl}_{3}, 100 \mathrm{MHz}\right) \delta 137.7,136.9,117.1,116.5,77.4,75.6,25.8,18.2,-$ 4.2, -4.9; HRMS calcd for $\mathrm{C}_{12} \mathrm{H}_{25} \mathrm{O}_{2} \mathrm{Si}\left(\mathrm{MH}^{+}\right)$229.1624, found 229.1660.

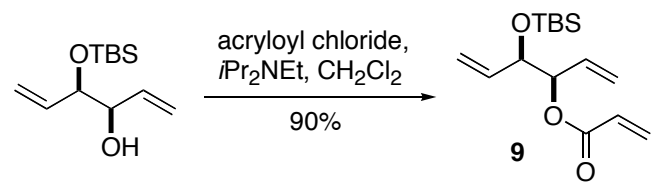

Acrylate Ester 9. To a solution of the mono-TBS ether of $\mathbf{1 0}(2.133 \mathrm{~g}, 9.33 \mathrm{mmol})$ in $\mathrm{CH}_{2} \mathrm{Cl}_{2}(93 \mathrm{~mL})$ at $0{ }^{\circ} \mathrm{C}$ was added $i \operatorname{Pr}_{2} \mathrm{NEt}(6.5 \mathrm{~mL}, 37.32 \mathrm{mmol})$ followed by acryloyl chloride $(1.52 \mathrm{~mL}, 18.66 \mathrm{mmol})$. The reaction mixture was warmed to room temperature and stirred for $12 \mathrm{~h}$, after which time it was quenched with $100 \mathrm{~mL}$ of water and diluted with $\mathrm{Et}_{2} \mathrm{O}(150 \mathrm{~mL})$. The layers were separated, and the aqueous phase was extracted with $\mathrm{Et}_{2} \mathrm{O}(3 \times 100$ $\mathrm{mL})$. The combined organic phases were washed with saturated $\mathrm{NH}_{4} \mathrm{Cl}(150 \mathrm{~mL})$ and brine $(150 \mathrm{~mL})$ and dried over $\mathrm{MgSO}_{4}$. The drying agent was removed by filtration, and solvents were removed in vacuo. Purification by silica gel chromatography $\left(12: 1\right.$ pentane/ $\left.\mathrm{Et}_{2} \mathrm{O}\right)$ gave acrylate ester $9(2.371 \mathrm{~g}, 90 \%)$ as a colorless oil. Data for 9: $[\alpha]_{\mathrm{D}}^{22}$ +62.9 (c 2.02, $\left.\mathrm{CH}_{2} \mathrm{Cl}_{2}\right)$; IR (thin film) 3095, 2957, 2930, 2887, 2858, $1734 \mathrm{~cm}^{-1} ;{ }^{1} \mathbf{H} \mathbf{N M R}\left(\mathrm{CDCl}_{3}, 400 \mathrm{MHz}\right) \delta 6.45$ $(\mathrm{dd}, J=17.4,1.6 \mathrm{~Hz}, 1 \mathrm{H}), 6.16(\mathrm{dd}, J=17.4,10.5 \mathrm{~Hz}, 1 \mathrm{H}), 5.88-5.78(\mathrm{~m}, 2 \mathrm{H}), 5.86(\mathrm{dd}, J=10.5,1.6 \mathrm{~Hz}, 1 \mathrm{H}), 5.32-$ $5.26(\mathrm{~m}, 3 \mathrm{H}), 5.23(\mathrm{dt}, J=10.7,1.4 \mathrm{~Hz}, 1 \mathrm{H}), 5.19(\mathrm{ddd}, J=10.5,2.0,1.4 \mathrm{~Hz}, 1 \mathrm{H}), 4.24(\mathrm{tt}, J=6.2,1.4 \mathrm{~Hz}, 1 \mathrm{H})$, 0.89 (s, 9H), 0.08 (s, 3H), 0.05 (s, 3H); ${ }^{13} \mathbf{C ~ N M R ~}\left(\mathrm{CDCl}_{3}, 100 \mathrm{MHz}\right) \delta 165.1,136.6,132.6,131.0,128.5,118.0$, 116.9, 77.1, 74.2, 25.7, 18.1, -4.6, -4.9; HRMS calcd for $\mathrm{C}_{15} \mathrm{H}_{27} \mathrm{O}_{3} \mathrm{Si}\left(\mathrm{MH}^{+}\right)$283.1729, found 283.1733.

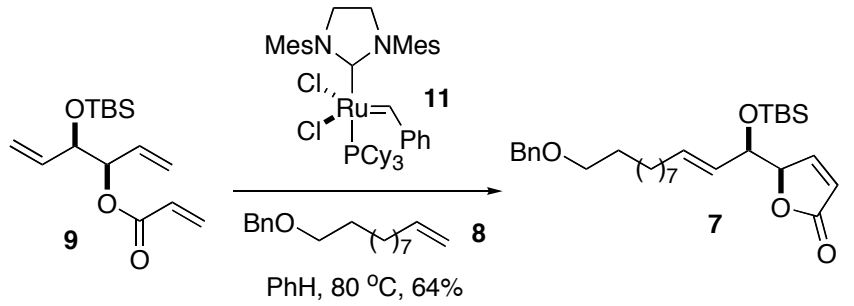

Metathesis Product 7. To a solution of acrylate ester 9 (1.020 g, $3.61 \mathrm{mmol})$ in $\mathrm{PhH}(360 \mathrm{~mL})$ was added the benzyl ether of 10-undecen-1-ol 8 (2.820 g, $10.83 \mathrm{mmol})$. The mixture was heated to reflux, and a solution of second generation Grubbs' catalyst $11(306.5 \mathrm{mg}, 0.36 \mathrm{mmol})$ in $\mathrm{PhH}(10 \mathrm{~mL})$ was added over a period of 10 hours by syringe pump. Heating was continued for $8 \mathrm{~h}$ after addition was complete. After cooling to room temperature, the mixture was filtered through a short pad of silica gel, and the filtrate was concentrated in vacuo. Purification by silica gel chromatography $\left(3: 1\right.$ hexanes/ $\left.\mathrm{Et}_{2} \mathrm{O}\right)$ gave metathesis product $7(1.124 \mathrm{~g}, 64 \%)$ as a slightly yellow oil. Data for 7: $[\alpha]_{\mathrm{D}}^{22}-36.3$ (c 1.67, $\mathrm{CHCl}_{3}$ ); IR (thin film) $3010,2928,2855,1762 \mathrm{~cm}^{-1} ;{ }^{1} \mathbf{H} \mathbf{N M R}\left(\mathrm{CDCl}_{3}, 400 \mathrm{MHz}\right) \delta$ $7.44(\mathrm{dd}, J=5.8,1.6 \mathrm{~Hz}, 1 \mathrm{H}), 7.36-7.26(\mathrm{~m}, 5 \mathrm{H}), 6.15(\mathrm{dd}, J=5.8,2.0 \mathrm{~Hz}, 1 \mathrm{H}), 5.69(\mathrm{dt}, J=15.4,6.8 \mathrm{~Hz}, 1 \mathrm{H}), 5.26$ $(\mathrm{ddt}, J=15.4,7.2,1.4 \mathrm{~Hz}, 1 \mathrm{H}), 4.95(\mathrm{dt}, J=5.5,1.8 \mathrm{~Hz}, 1 \mathrm{H}), 4.51(\mathrm{~s}, 2 \mathrm{H}), 4.33(\mathrm{br} \mathrm{t}, J=6.3 \mathrm{~Hz}, 1 \mathrm{H}), 3.47(\mathrm{t}, J=$ $6.6 \mathrm{~Hz}, 2 \mathrm{H}), 2.00(\mathrm{q}, J=6.8 \mathrm{~Hz}, 2 \mathrm{H}), 1.62(\mathrm{~m}, 2 \mathrm{H}), 1.39-1.21(\mathrm{~m}, 12 \mathrm{H}), 0.90(\mathrm{~s}, 9 \mathrm{H}), 0.09(\mathrm{~s}, 3 \mathrm{H}), 0.05(\mathrm{~s}, 3 \mathrm{H}) ;{ }^{13} \mathrm{C}$ NMR $\left(\mathrm{CDCl}_{3}, 100 \mathrm{MHz}\right) \delta 172.9,153.9,138.7,135.5,128.3,127.6,127.4,126.6,122.8,85.7,73.6,72.8,70.5$, $32.1,29.7,29.5,29.4,29.3,29.0,28.9,26.2,25.7,18.1,-4.4,-5.0$; HRMS calcd for $\mathrm{C}_{29} \mathrm{H}_{47} \mathrm{O}_{4} \mathrm{Si}_{(}\left(\mathrm{MH}^{+}\right) 487.3244$, found 487.3219 . 


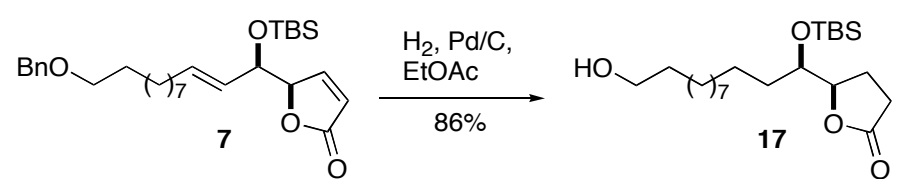

Alcohol 17. To a solution of metathesis product $7(995.6 \mathrm{mg}, 2.05 \mathrm{mmol})$ in EtOAc $(25 \mathrm{~mL})$ at room temperature was added approximately $100 \mathrm{mg}$ of $10 \mathrm{wt} . \% \mathrm{Pd}$ on activated carbon. The reaction mixture was stirred under 1 atmosphere of $\mathrm{H}_{2}$ for 8 hours after which time it was filtered through a pad of silica gel with EtOAc and concentrated in vacuo. Purification by silica gel column chromatography (3:1 hexanes/EtOAc) gave alcohol 17 (706.4 mg, 86\%) as a colorless oil. Data for 17: $[\alpha]^{22}{ }_{\mathrm{D}}-69.6\left(c\right.$ 1.70, $\left.\mathrm{CHCl}_{3}\right)$; IR (thin film) 3462, 3019, 2929, 2856, $1768 \mathrm{~cm}^{-1} ;{ }^{1} \mathbf{H}$ NMR $\left(\mathrm{CDCl}_{3}, 400 \mathrm{MHz}\right) \delta 4.41$ (ddd, $\left.J=7.6,6.1,4.3 \mathrm{~Hz}, 1 \mathrm{H}\right), 3.59(\mathrm{td}, J=6.1,4.5 \mathrm{~Hz}, 1 \mathrm{H})$, $3.56(\mathrm{t}, J=6.7 \mathrm{~Hz}, 2 \mathrm{H}), 2.49(\mathrm{ddd}, J=18.0,10.1,6.2 \mathrm{~Hz}, 1 \mathrm{H}), 2.39(\mathrm{ddd}, J=17.6,10.1,7.4 \mathrm{~Hz}, 1 \mathrm{H}), 2.14(\mathrm{~m}, 1 \mathrm{H})$, $1.95(\mathrm{~m}, 1 \mathrm{H}), 1.57-1.45(\mathrm{~m}, 3 \mathrm{H}), 1.40-1.12(\mathrm{~m}, 18 \mathrm{H}), 0.81(\mathrm{~s}, 9 \mathrm{H}), 0.01(\mathrm{~s}, 3 \mathrm{H}), 0.00(\mathrm{~s}, 3 \mathrm{H}) ;{ }^{13} \mathbf{C} \mathbf{N M R}\left(\mathrm{CDCl}_{3}, 100\right.$ MHz) $\delta$ 177.5, 81.6, 74.1, 63.0, 32.7, 32.6, 29.7, 29.5, 29.4, 29.3, 28.6, 25.8, 25.7, 25.2, 23.6, 18.0, -4.5; HRMS calcd for $\mathrm{C}_{22} \mathrm{H}_{45} \mathrm{O}_{4} \mathrm{Si}\left(\mathrm{MH}^{+}\right)$401.3087, found 401.3074 .

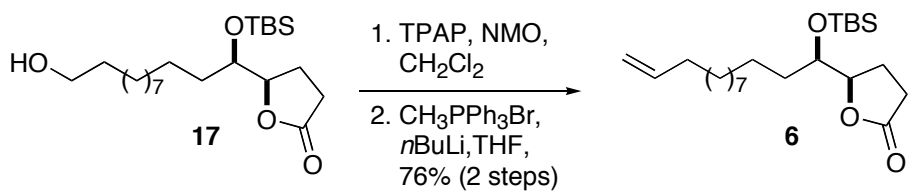

Alkene 6. To a solution of alcohol $17(540.5 \mathrm{mg}, 1.35 \mathrm{mmol})$ in $\mathrm{CH}_{2} \mathrm{Cl}_{2}(15 \mathrm{~mL})$ at room temperature was added crushed $4 \AA$ molecular sieves $(\sim 500 \mathrm{mg})$. The slurry was cooled to $0{ }^{\circ} \mathrm{C}$, and $\mathrm{NMO}(237.8 \mathrm{mg}, 2.03 \mathrm{mmol})$ and TPAP (94.9 mg, $0.27 \mathrm{mmol}$ ) were added sequentially. The greenish black slurry was stirred for 10 minutes at $0{ }^{\circ} \mathrm{C}$. The reaction mixture was filtered through a short pad of silica gel with EtOAc, and the filtrate was concentrated in vacuo to give $499.0 \mathrm{mg}$ of the corresponding aldehyde, which was used without purification in the next step.

The crude aldehyde $(499.0 \mathrm{mg}, 1.25 \mathrm{mmol})$ was dissolved in THF $(12 \mathrm{~mL})$, and the solution was cooled to $-10{ }^{\circ} \mathrm{C}$. In a separate flask, $\mathrm{CH}_{3} \mathrm{PPh}_{3} \mathrm{Br}(1.446 \mathrm{~g}, 4.05 \mathrm{mmol})$ in THF $(15 \mathrm{~mL})$ and cooled to $0{ }^{\circ} \mathrm{C} .2 .53 \mathrm{~mL}$ of a 1.6 $\mathrm{M}$ solution of $n \mathrm{BuLi}$ in hexanes $(4.05 \mathrm{mmol})$ was added, and the resulting bright yellow solution was stirred for 30 minutes. The $0.23 \mathrm{M}$ solution of Wittig reagent was added dropwise via syringe to the crude aldehyde until the yellow color persisted, and the slurry was stirred at $-10{ }^{\circ} \mathrm{C}$ for an additional 5 minutes. The reaction was quenched by addition of $\mathrm{H}_{2} \mathrm{O}(40 \mathrm{~mL})$ and diluted with $\mathrm{Et}_{2} \mathrm{O}(50 \mathrm{~mL})$. The layers were separated, and the aqueous phase was extracted with $\mathrm{Et}_{2} \mathrm{O}(3 \times 50 \mathrm{~mL})$. The combined organic layers were washed with $0.1 \mathrm{M} \mathrm{HCl}(40 \mathrm{~mL})$ and brine $(40$ $\mathrm{mL}$ ) and dried over $\mathrm{MgSO}_{4}$. The drying agent was removed by filtration, and the filtrate was concentrated in vacuo. Purification by silica gel column chromatography (8:1 hexanes/EtOAc) gave alkene $\mathbf{6}(407.0 \mathrm{mg}, 76 \%$ from 17) as a colorless oil. Data for 6: $[\alpha]^{22}{ }_{\mathrm{D}}-25.5\left(c\right.$ 1.54, $\mathrm{CHCl}_{3}$ ); IR (thin film) 3076, 2926, 2855, $1784 \mathrm{~cm}^{-1}$; ${ }^{1} \mathbf{H}$ NMR $\left(\mathrm{CDCl}_{3}, 400 \mathrm{MHz}\right) \delta 5.73$ (ddt, $\left.J=17.1,10.2,6.8 \mathrm{~Hz}, 1 \mathrm{H}\right), 4.93(\mathrm{dq}, J=17.1,1.2 \mathrm{~Hz}, 1 \mathrm{H}), 4.85$ (ddt, $J=10.2,2.3$, $1.2 \mathrm{~Hz}, 1 \mathrm{H}), 4.41(\mathrm{ddd}, J=7.6,6.1,4.3 \mathrm{~Hz}, 1 \mathrm{H}), 3.59(\mathrm{td}, J=6.1,4.3 \mathrm{~Hz}, 1 \mathrm{H}), 2.49(\mathrm{ddd}, J=17.8,10.1,6.2 \mathrm{~Hz}$, 1H), 2.39 (ddd, $J=17.4,10.1,7.4 \mathrm{~Hz}, 1 \mathrm{H}), 2.13(\mathrm{~m}, 1 \mathrm{H}), 2.00-1.91(\mathrm{~m}, 3 \mathrm{H}), 1.52(\mathrm{~m}, 1 \mathrm{H}), 1.39-1.17(\mathrm{~m}, 17 \mathrm{H}), 0.81$ (s, 9H), 0.01 (s, 3H), 0.00 (s, 3H); ${ }^{13} \mathbf{C}$ NMR $\left(\mathrm{CDCl}_{3}, 100 \mathrm{MHz}\right) \delta 177.4,139.2,114.1,81.6,74.2,33.8,32.6,29.7$, 
29.5, 29.4, 29.1, 28.9, 28.6, 25.8, 25.2, 23.6, 18.0, -4.5; HRMS calcd for $\mathrm{C}_{23} \mathrm{H}_{45} \mathrm{O}_{3} \mathrm{Si}\left(\mathrm{MH}^{+}\right)$397.3138, found 397.3184.

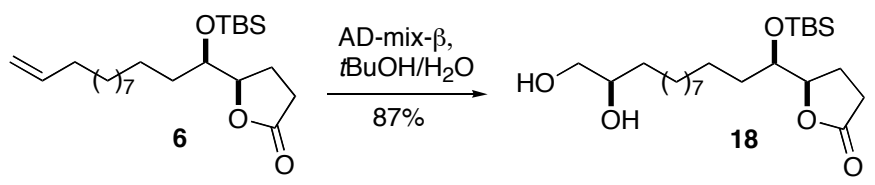

Diol 18. Alkene $6(593.1 \mathrm{mg}, 1.50 \mathrm{mmol})$ was dissolved in $7.5 \mathrm{~mL}$ of $t \mathrm{BuOH}$ and $7.5 \mathrm{~mL}$ of $\mathrm{H}_{2} \mathrm{O}$ and cooled to 0 ${ }^{\circ} \mathrm{C}$. AD-mix $-\beta(2.101 \mathrm{~g})$ was added, and the slurry was stirred at $0{ }^{\circ} \mathrm{C}$ for $36 \mathrm{~h}$. The reaction was quenched by addition of sat. $\mathrm{Na}_{2} \mathrm{~S}_{2} \mathrm{O}_{3}(15 \mathrm{~mL})$, warmed to room temperature, and stirred for $1 \mathrm{~h}$. The mixture was extracted with EtOAc $(6 \times 30 \mathrm{~mL})$, and the organic extracts were dried over $\mathrm{MgSO}_{4}$. The drying agent was removed by filtration, and the filtrate was concentrated in vacuo. Purification by silica gel column chromatography (2:1 EtOAc/hexanes) gave diol $18(561.5 \mathrm{mg}, 87 \%)$ as a colorless oil. Data for 18: $[\alpha]_{\mathrm{D}}^{22}+19.3\left(c 1.05, \mathrm{CHCl}_{3}\right)$; IR (thin film) 3422 , 2928, 2855, $1773 \mathrm{~cm}^{-1} ;{ }^{1} \mathbf{H}$ NMR $\left(\mathrm{CDCl}_{3}, 400 \mathrm{MHz}\right) \delta 4.43(\mathrm{ddd}, J=7.6,6.1,4.3 \mathrm{~Hz}, 1 \mathrm{H}), 3.62(\mathrm{~m}, 2 \mathrm{H}), 3.59(\mathrm{dd}, J$ $=10.9,3.1 \mathrm{~Hz}, 1 \mathrm{H}), 3.37(\mathrm{dd}, J=10.9,7.6 \mathrm{~Hz}, 1 \mathrm{H}), 2.51(\mathrm{ddd}, J=18.0,10.1,6.3 \mathrm{~Hz}, 1 \mathrm{H}), 2.40(\mathrm{ddd}, J=17.6,10.1$, $7.6 \mathrm{~Hz}, 1 \mathrm{H}), 2.14(\mathrm{~m}, 1 \mathrm{H}), 1.97(\mathrm{~m}, 1 \mathrm{H}), 1.52(\mathrm{sex}, J=7.0 \mathrm{~Hz}, 1 \mathrm{H}), 1.42-1.15(\mathrm{~m}, 19 \mathrm{H}), 0.82(\mathrm{~s}, 9 \mathrm{H}), 0.02$ (s, 3H), $0.01(\mathrm{~s}, 3 \mathrm{H}) ;{ }^{13} \mathbf{C} \mathbf{N M R}\left(\mathrm{CDCl}_{3}, 100 \mathrm{MHz}\right) \delta$ 177.5, 81.6, 74.1, 72.3, 66.8, 33.1, 32.6, 29.7, 29.6, 29.4, 28.6, 25.8, 25.5, 25.2, 23.6, 18.0, -4.5; HRMS calcd for $\mathrm{C}_{23} \mathrm{H}_{47} \mathrm{O}_{5} \mathrm{Si}\left(\mathrm{MH}^{+}\right)$431.3193, found 431.3187.

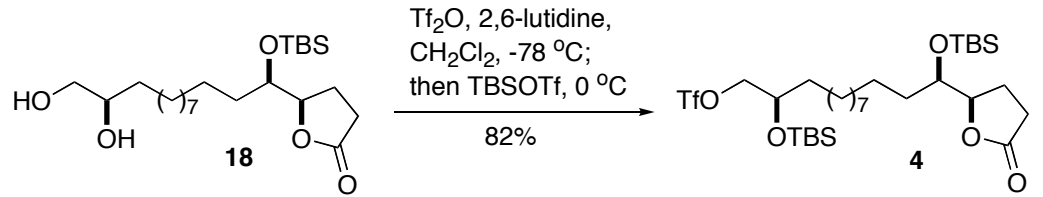

Triflate 4. To a solution of diol $18(231.1 \mathrm{mg}, 0.54 \mathrm{mmol})$ and 2,6-lutidine $\left(300 \mu \mathrm{L}, 2.57 \mathrm{mmol}^{2}\right.$ in $\mathrm{CH}_{2} \mathrm{Cl}_{2}(5.4$ $\mathrm{mL})$ at $-78{ }^{\circ} \mathrm{C}$ was added $\mathrm{Tf}_{2} \mathrm{O}(96 \mu \mathrm{L}, 0.57 \mathrm{mmol})$. After 10 minutes, TBSOTf $(190 \mu \mathrm{L}, 0.81 \mathrm{mmol})$ was added, and the reaction mixture was stirred for an additional 30 minutes at $0{ }^{\circ} \mathrm{C}$. The reaction was quenched by addition of sat. $\mathrm{NH}_{4} \mathrm{Cl}(10 \mathrm{~mL})$ and diluted with EtOAc. The layers were separated, and the aqueous phase was extracted with EtOAc $(3 \times 15 \mathrm{~mL})$. The combined organic phases were washed with sat. $\mathrm{NH}_{4} \mathrm{Cl}(15 \mathrm{~mL}), \mathrm{H}_{2} \mathrm{O}(15 \mathrm{~mL})$, and brine $(15 \mathrm{~mL})$ and dried over $\mathrm{Na}_{2} \mathrm{SO}_{4}$. The drying agent was removed by filtration, and the filtrate was concentrated in vacuo. Purification by silica gel column chromatography (6:1 hexanes/EtOAc) gave triflate 4 (299.8 mg, $82 \%)$ as a colorless oil. The triflate was unstable and therefore used immediately in the next step.

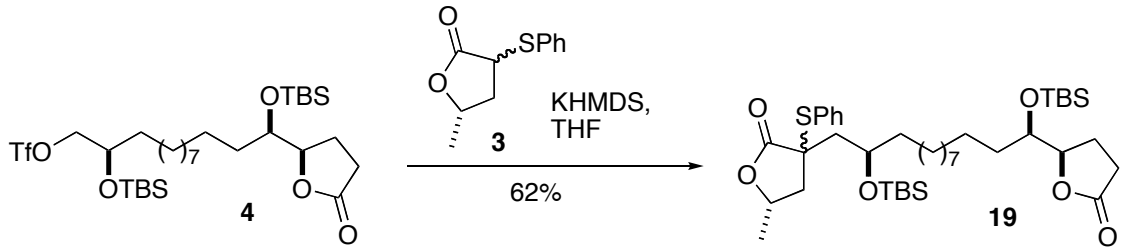

Sulfide 19. (5S)-Methyl-3-phenylsulfanyldihydrofuran-2-one 3 (92.2 mg, $0.44 \mathrm{mmol})$ in THF (0.40 mL) was cooled to $0{ }^{\circ} \mathrm{C}$, and $0.88 \mathrm{~mL}$ of a $0.5 \mathrm{M}$ solution of $\mathrm{KHMDS}$ in $\mathrm{PhCH}_{3}(0.44 \mathrm{mmol})$ was added. The resulting pale yellow 
solution was stirred at $0{ }^{\circ} \mathrm{C}$ for 10 minutes after which time triflate $4(299.8 \mathrm{mg}, 0.44 \mathrm{mmol})$ in $0.4 \mathrm{~mL}$ of THF was added via syringe. The reaction mixture was warmed to room temperature and stirred for $16 \mathrm{~h}$. The reaction was quenched by addition of sat. $\mathrm{NH}_{4} \mathrm{Cl}(5 \mathrm{~mL})$ and diluted with EtOAc. The layers were separated, and the aqueous phase was extracted with EtOAc $(3 \times 10 \mathrm{~mL})$. The combined organic extracts were washed with sat. $\mathrm{NH}_{4} \mathrm{Cl}(10 \mathrm{~mL})$, $\mathrm{H}_{2} \mathrm{O}(10 \mathrm{~mL})$, and brine $(10 \mathrm{~mL})$ and dried over $\mathrm{Na}_{2} \mathrm{SO}_{4}$. The drying agent was removed by filtration, and the filtrate was concentrated in vacuo. Purification by silica gel column chromatography (6:1 hexanes/EtOAc) gave sulfide 19 (200.4 mg, 62\%) as an inseparable 12:1 mixture of diastereomers. Data for 19: IR (thin film) 3060, 2928, 2855, $1778 \mathrm{~cm}^{-1}$; ${ }^{1} \mathbf{H}$ NMR $\left(\mathrm{CDCl}_{3}, 400 \mathrm{MHz}\right.$, major isomer) $\delta$ 7.58-7.32 (m, 5H), 4.55-4.47 (m, 2H), $4.26(\mathrm{~m}$, 1H), $3.68(\mathrm{q}, J=5.6 \mathrm{~Hz}, 1 \mathrm{H}), 3.05(\mathrm{dd}, J=14.1,7.6 \mathrm{~Hz}, 1 \mathrm{H}), 2.57$ (ddd, $J=17.8,10.0,6.1 \mathrm{~Hz}, 1 \mathrm{H}), 2.47$ (ddd, $J=$ 17.6, 10.0, 7.6 Hz, 1H), $2.21(\mathrm{~m}, 1 \mathrm{H}), 2.09-1.95(\mathrm{~m}, 2 \mathrm{H}), 1.88(\mathrm{dd}, J=15.2,8.6 \mathrm{~Hz}, 1 \mathrm{H}), 1.84(\mathrm{dd}, J=14.1,6.4 \mathrm{~Hz}$, 1H), $1.60(\mathrm{sex}, J=6.5 \mathrm{~Hz}, 1 \mathrm{H}), 1.50-1.19$ (m, 22H), 0.91 (s, 9H), 0.90 (s, 9H), 0.16 (s, 3H), 0.12 (s, 3H), 0.10 (s, 3H), 0.09 (s, 3H); ${ }^{13} \mathbf{C}$ NMR ( $\mathrm{CDCl}_{3}, 100 \mathrm{MHz}$, major isomer) $\delta$ 177.6, 177.4, 136.7, 130.4, 129.6, 129.0, 81.6, 74.2, 73.3, 70.2, 69.5, 55.5, 41.2, 39.4, 38.5, 32.7, 29.7, 29.5, 28.6, 26.0, 25.9, 25.8, 25.2, 24.4, 23.6, 22.0, 18.1, 18.0, $3.9,-4.5, ;$ HRMS calcd for $\mathrm{C}_{40} \mathrm{H}_{71} \mathrm{O}_{6} \mathrm{SSi}_{2}\left(\mathrm{MH}^{+}\right)$735.4510, found 735.4493 .

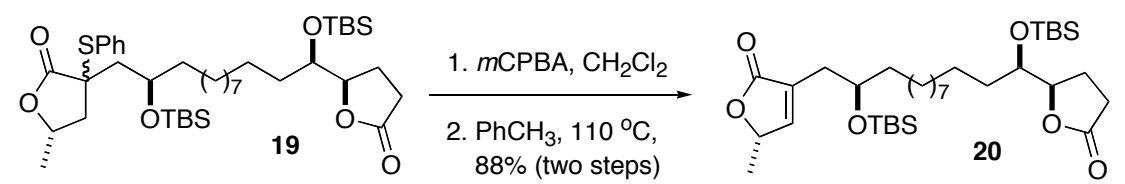

Butenolide 20. To a solution of sulfide $19(90.2 \mathrm{mg}, 0.12 \mathrm{mmol})$ in $\mathrm{CH}_{2} \mathrm{Cl}_{2}(2.4 \mathrm{~mL})$ at $0{ }^{\circ} \mathrm{C}$ was added $m \mathrm{CPBA}$ (77\% max., $29.6 \mathrm{mg}, 0.13 \mathrm{mmol})$. After 30 minutes, the reaction was quenched by addition of sat. $\mathrm{NaHCO}_{3}(5 \mathrm{~mL})$ and diluted with EtOAc. The layers were separated, and the aqueous phase was extracted with EtOAc $(2 \times 10 \mathrm{~mL})$. The combined organic extracts were washed with sat. $\mathrm{NaHCO}_{3}(5 \mathrm{~mL})$ and brine $(5 \mathrm{~mL})$ and dried over $\mathrm{Na}_{2} \mathrm{SO}_{4}$. The drying agent was removed by filtration, and the filtrate was concentrated in vacuo. The crude sulfoxide was dissolved in $\mathrm{PhCH}_{3}(3 \mathrm{~mL})$ and heated to $110{ }^{\circ} \mathrm{C}$ for 20 minutes. The solution was filtered through a short pad of silica gel with EtOAc to give butenolide $20(65.9 \mathrm{mg}, 88 \%)$ as a colorless oil, which was used without further purification. Data for 20: $[\alpha]^{22}{ }_{\mathrm{D}}-37.7\left(c 0.67, \mathrm{CHCl}_{3}\right)$; IR (thin film) 2927.8, 2855, 1775, 1758, $\mathrm{cm}^{-1} ;{ }^{1} \mathbf{H}$ NMR $\left(\mathrm{CDCl}_{3}, 400 \mathrm{MHz}\right) \delta 7.13(\mathrm{br} \mathrm{s}, 1 \mathrm{H}), 5.01(\mathrm{q}, J=6.7 \mathrm{~Hz}, 1 \mathrm{H}), 4.49(\mathrm{q}, J=5.9 \mathrm{~Hz}, 1 \mathrm{H}), 3.95(\mathrm{p}, J=5.5 \mathrm{~Hz}, 1 \mathrm{H})$, $3.67(\mathrm{q}, J=5.9 \mathrm{~Hz}, 1 \mathrm{H}), 2.61-2.42(\mathrm{~m}, 4 \mathrm{H}), 2.21(\mathrm{~m}, 1 \mathrm{H}), 2.04(\mathrm{~m}, 1 \mathrm{H}), 1.60(\mathrm{sex}, J=7.0 \mathrm{~Hz}, 1 \mathrm{H}), 1.47-1.20(\mathrm{~m}$, $19 \mathrm{H}), 1.42$ (d, $J=6.7 \mathrm{~Hz}, 3 \mathrm{H}), 0.90$ (s, 9H), 0.87 (s, 9H), 0.10 (s, 3H), 0.08 (s, 3H), 0.05 (s, 3H), 0.03 (s, 3H); ${ }^{13} \mathbf{C}$ NMR $\left(\mathrm{CDCl}_{3}, 100 \mathrm{MHz}\right) \delta 177.4,174.0,151.5,130.8,81.6,77.5,74.2,70.2,37.0,32.7,29.7,29.6,29.5,28.6,25.9$, 25.8, 25.2, 25.1, 23.6, 19.0, 18.0, -4.5; HRMS calcd for $\mathrm{C}_{34} \mathrm{H}_{65} \mathrm{O}_{6} \mathrm{Si}_{2}\left(\mathrm{MH}^{+}\right)$625.4320, found 625.4356.

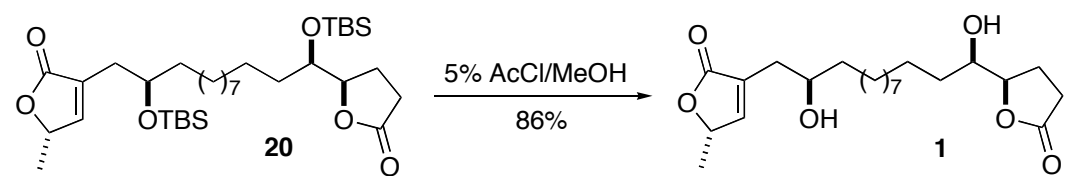

Rollicosin (1). To a solution of butenolide $20(60.1 \mathrm{mg}, 0.096 \mathrm{mmol})$ in $\mathrm{MeOH}(1 \mathrm{~mL})$ at $0{ }^{\circ} \mathrm{C}$ was added $1 \mathrm{~mL}$ of $5 \%(\mathrm{v} / \mathrm{v}) \mathrm{AcCl}$ in $\mathrm{MeOH}$ before being warmed to room temperature and stirred for $3 \mathrm{~h}$. The solution was diluted 
with $\mathrm{CH}_{2} \mathrm{Cl}_{2}$, and solid $\mathrm{NaHCO}_{3}$ was added until a neutral $\mathrm{pH}$ was reached. The mixture was filtered through a short pad of Celite with EtOAc, and the filtrate was concentrated in vacuo. Purification by silica gel column chromatography (96:4 $\left.\mathrm{CHCl}_{3} / \mathrm{MeOH}\right)$ gave rollicosin $1(32.7 \mathrm{mg}, 86 \%)$ as a white solid. Data for $\mathbf{1}: \mathrm{mp}=102-104$ ${ }^{\circ} \mathrm{C} ;[\alpha]^{22}{ }_{\mathrm{D}}-23.3$ (c 0.41, $\mathrm{CHCl}_{3}$ ); IR (thin film) 3408, 2918, 2850, 1769, $1746 \mathrm{~cm}^{-1} ;{ }^{1} \mathbf{H} \mathbf{N M R}\left(\mathrm{CDCl}_{3}, 400 \mathrm{MHz}\right) \delta$ $7.19(\mathrm{~d}, J=1.5 \mathrm{~Hz}, 1 \mathrm{H}), 5.06(\mathrm{qd}, J=6.8,1.5 \mathrm{~Hz}, 1 \mathrm{H}), 4.42(\mathrm{td}, J=7.4,4.9 \mathrm{~Hz}, 1 \mathrm{H}), 3.84(\mathrm{~m}, 1 \mathrm{H}), 3.57$ (dt, $J=7.4$, $4.9 \mathrm{~Hz}, 1 \mathrm{H}), 2.62(\mathrm{ddd}, J=17.8,10.0,5.1 \mathrm{~Hz}, 1 \mathrm{H}), 2.56-2.50(\mathrm{~m}, 1 \mathrm{H}), 2.54(\mathrm{dt}, J=17.8,9.0 \mathrm{~Hz}, 1 \mathrm{H}), 2.40(\mathrm{dd}, J=$ 15.2, $8.4 \mathrm{~Hz}, 1 \mathrm{H}), 2.26(\mathrm{~m}, 1 \mathrm{H}), 2.12(\mathrm{~m}, 1 \mathrm{H}), 1.60-1.25(\mathrm{~m}, 20 \mathrm{H}), 1.43(\mathrm{~d}, J=6.8 \mathrm{~Hz}, 3 \mathrm{H}) ;{ }^{13} \mathbf{C} \mathbf{N M R}\left(\mathrm{CDCl}_{3}, 100\right.$ MHz) $\delta 177.2,174.6,151.9,131.1,82.9,78.0,73.6,69.9,37.3,33.3,32.9,29.4,28.7,25.5,25.4,24.1,19.1$; HRMS calcd for $\mathrm{C}_{22} \mathrm{H}_{37} \mathrm{O}_{6}\left(\mathrm{MH}^{+}\right)$397.2590, found 397.2593.

\section{References.}

(1) Burke, S. D.; Sametz, G. M. Org. Lett. 1999, 1, 72.

(2) Chow, S.; Kitching, W. Tetrahedron: Asymmetry 2002, 13, 779.

(3) White, J. D.; Somers, T. C.; Reddy, G. N. J. Org. Chem. 1992, 57, 4991. 
${ }^{1} \mathrm{H}$ and ${ }^{13} \mathrm{C}$ NMR Spectra.

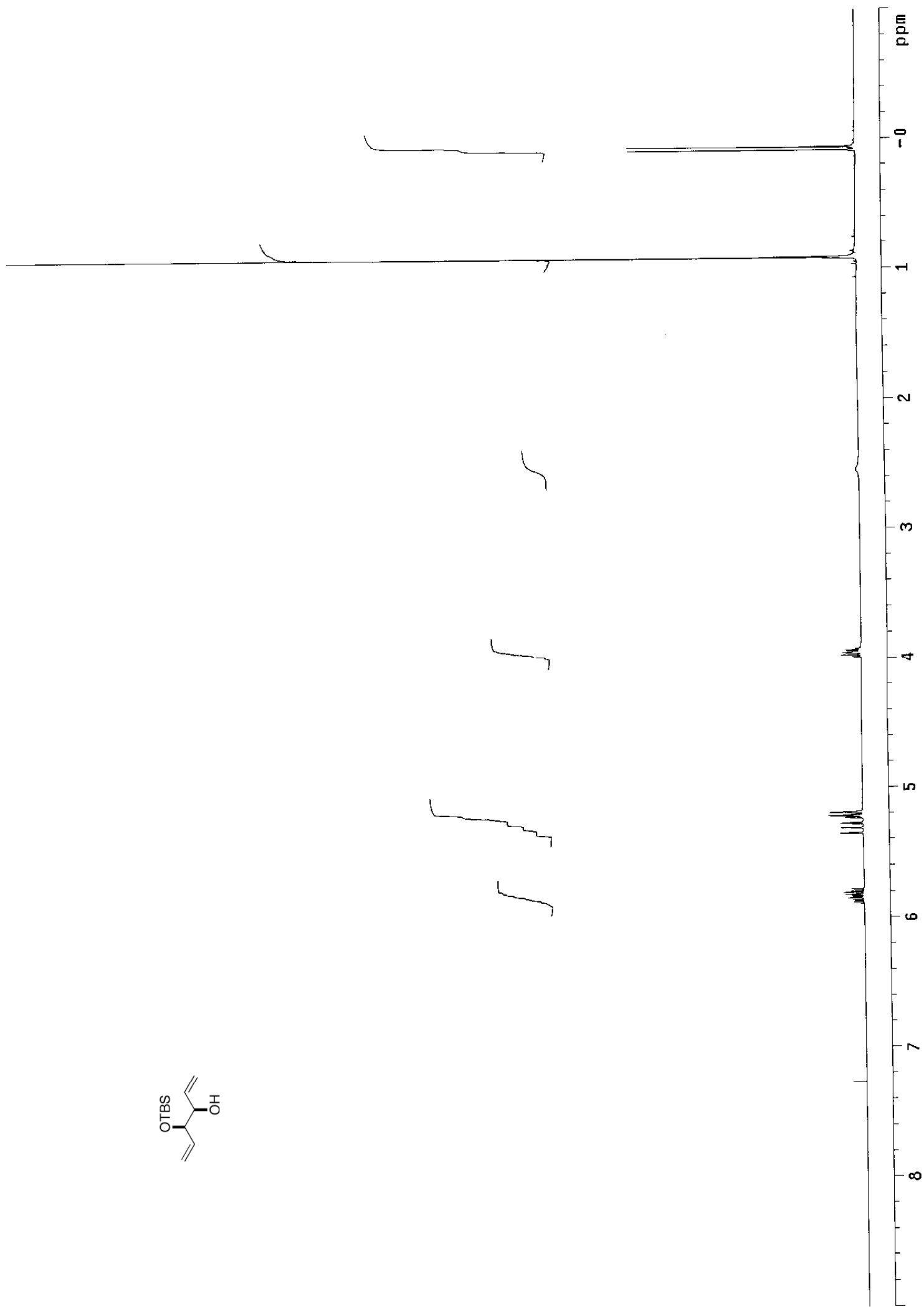




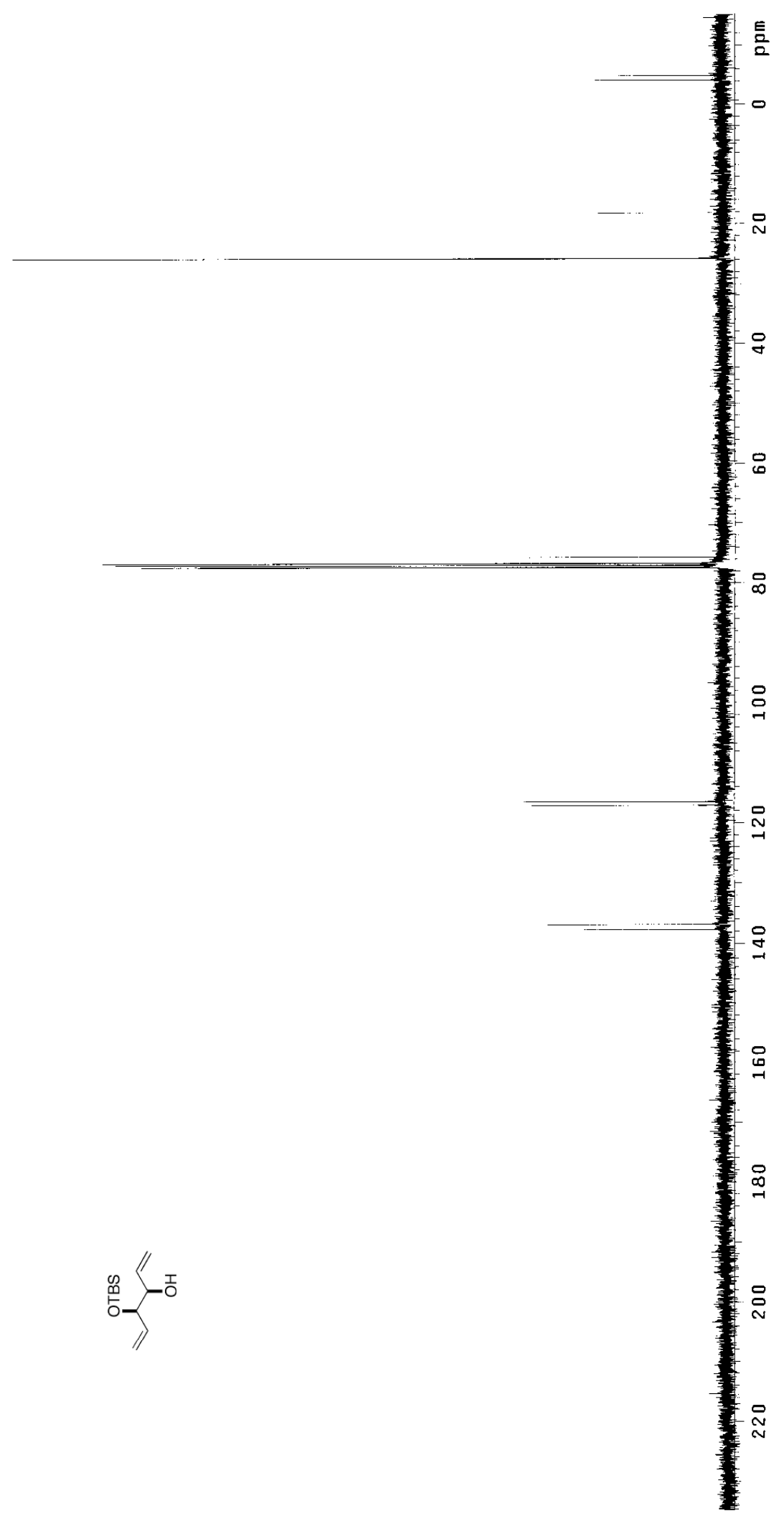




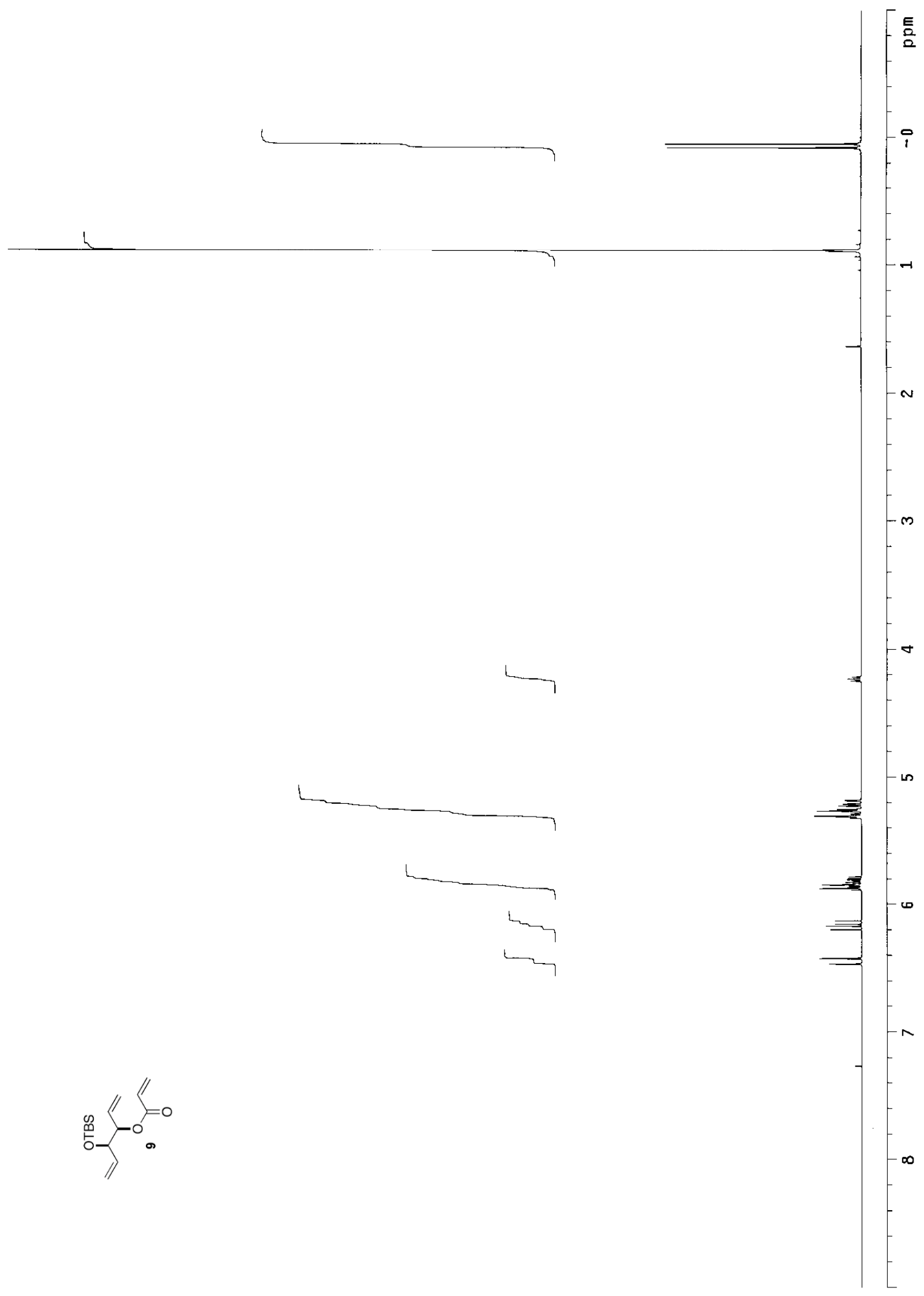




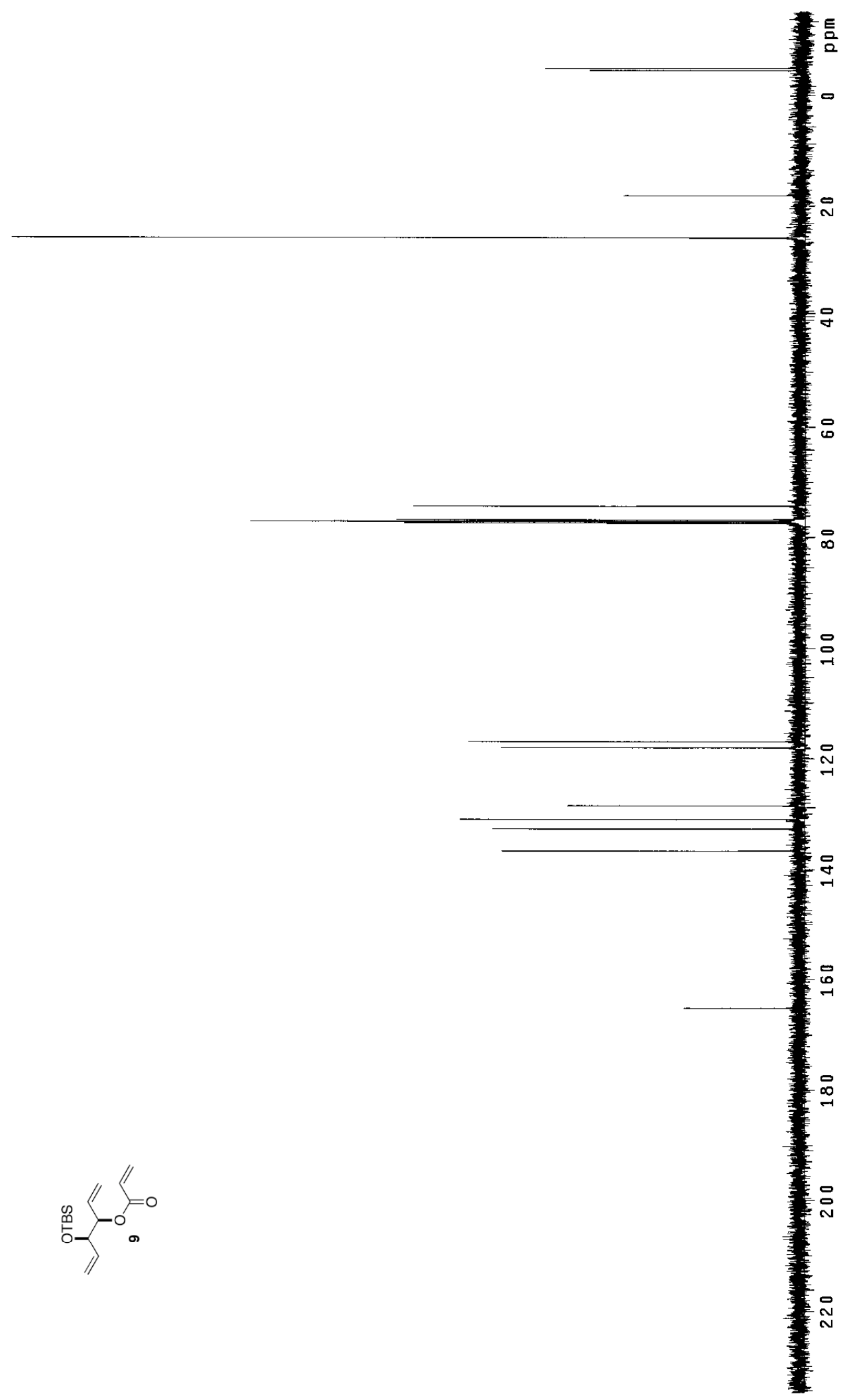




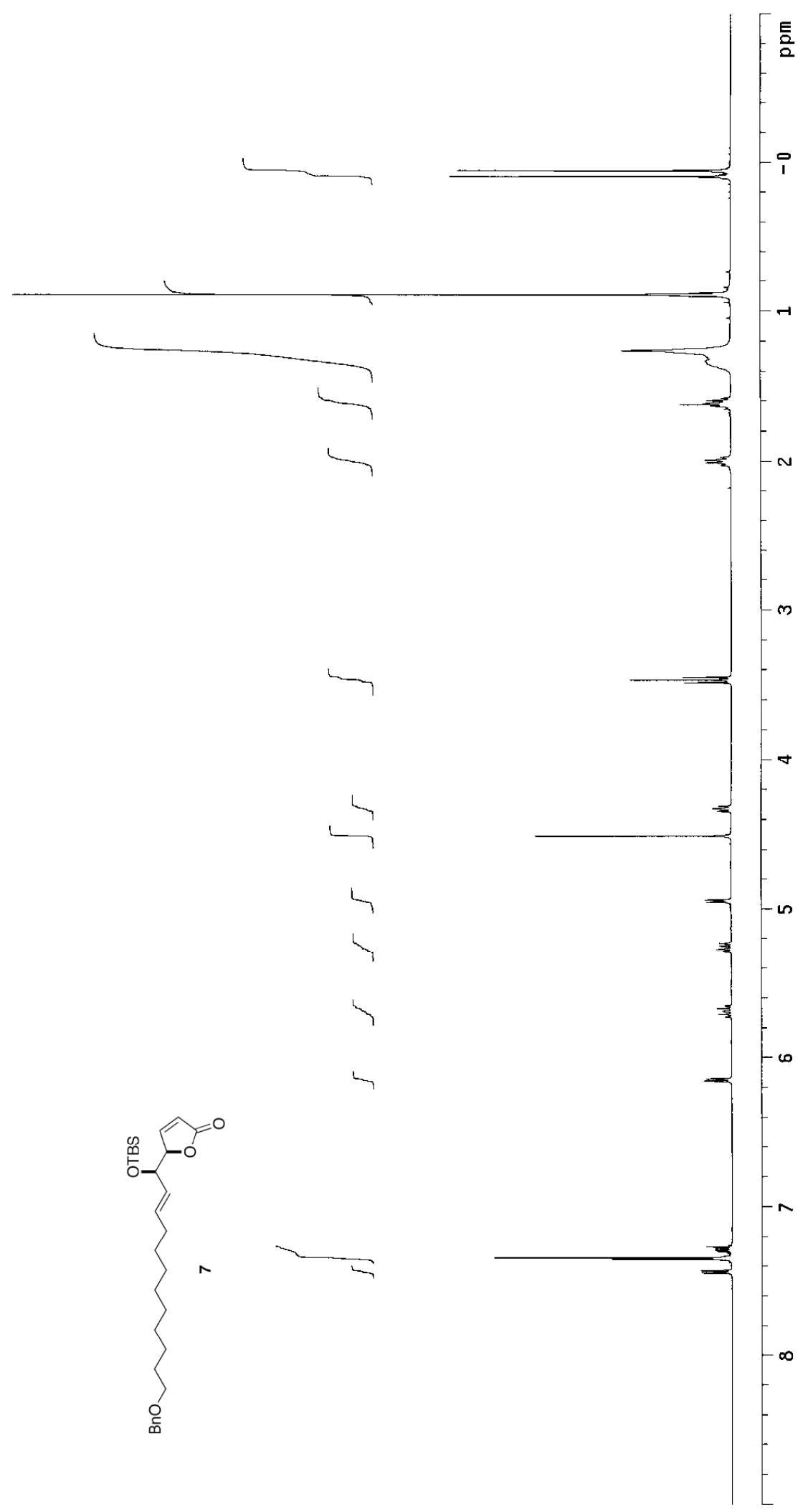




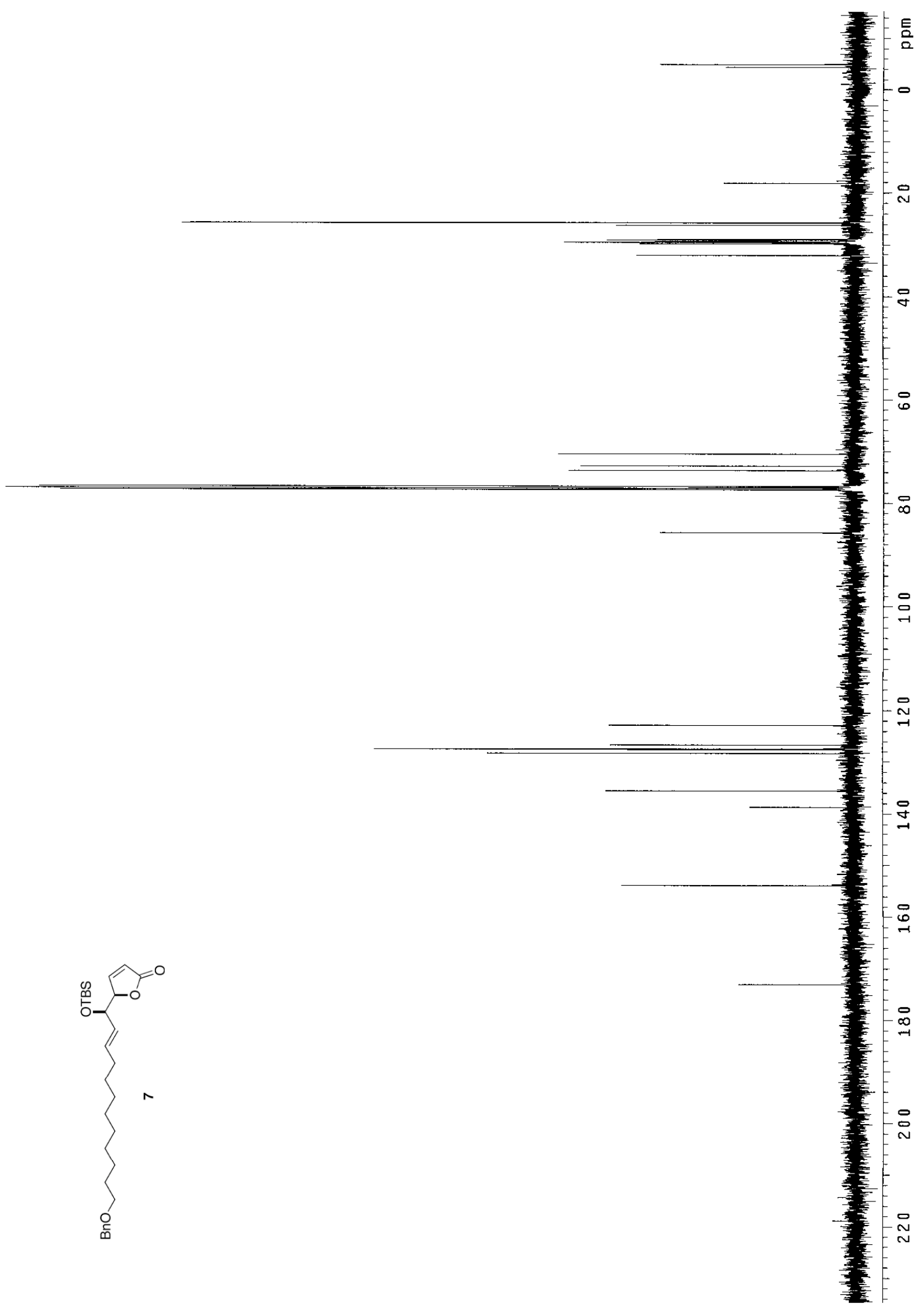

S12 


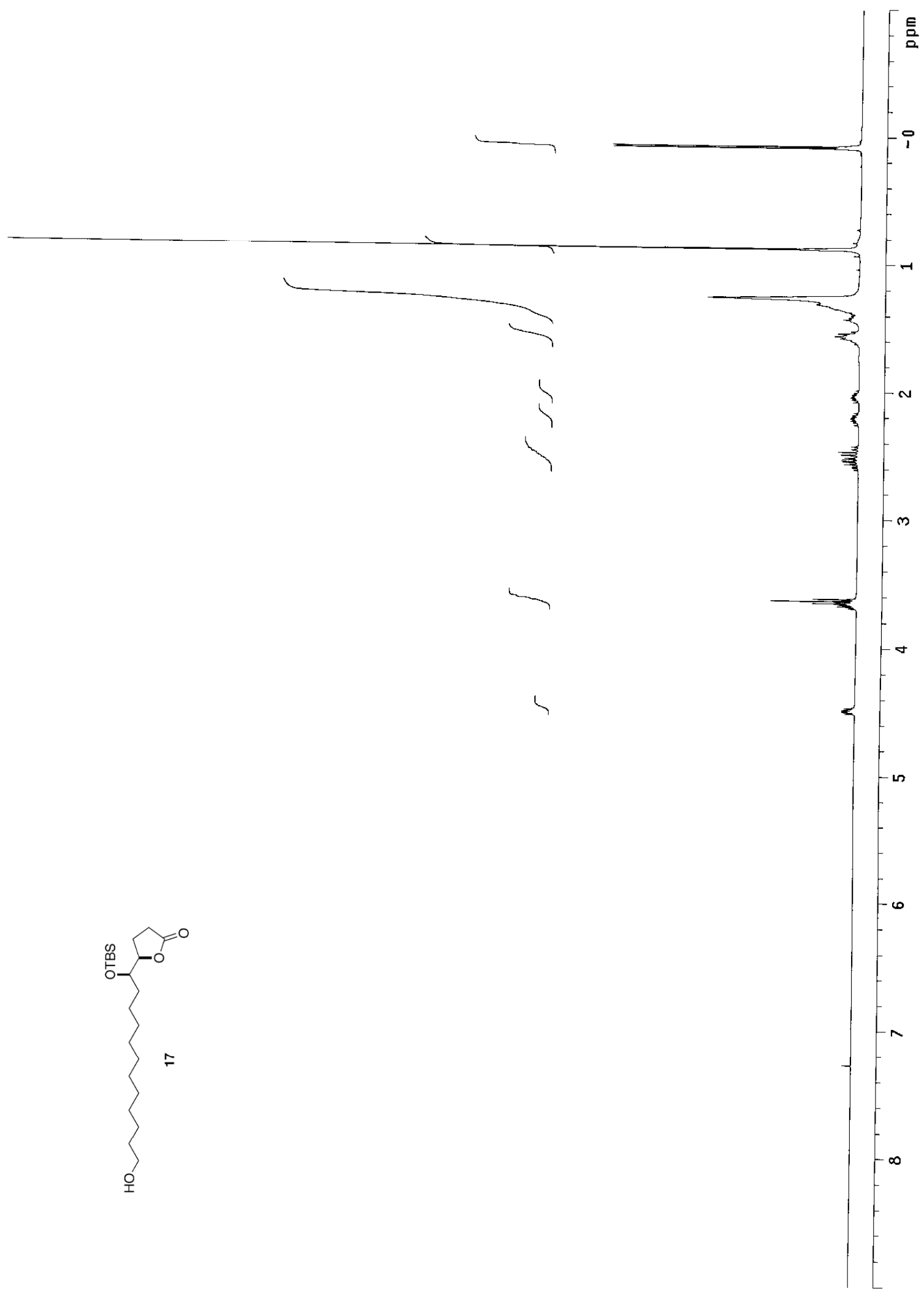




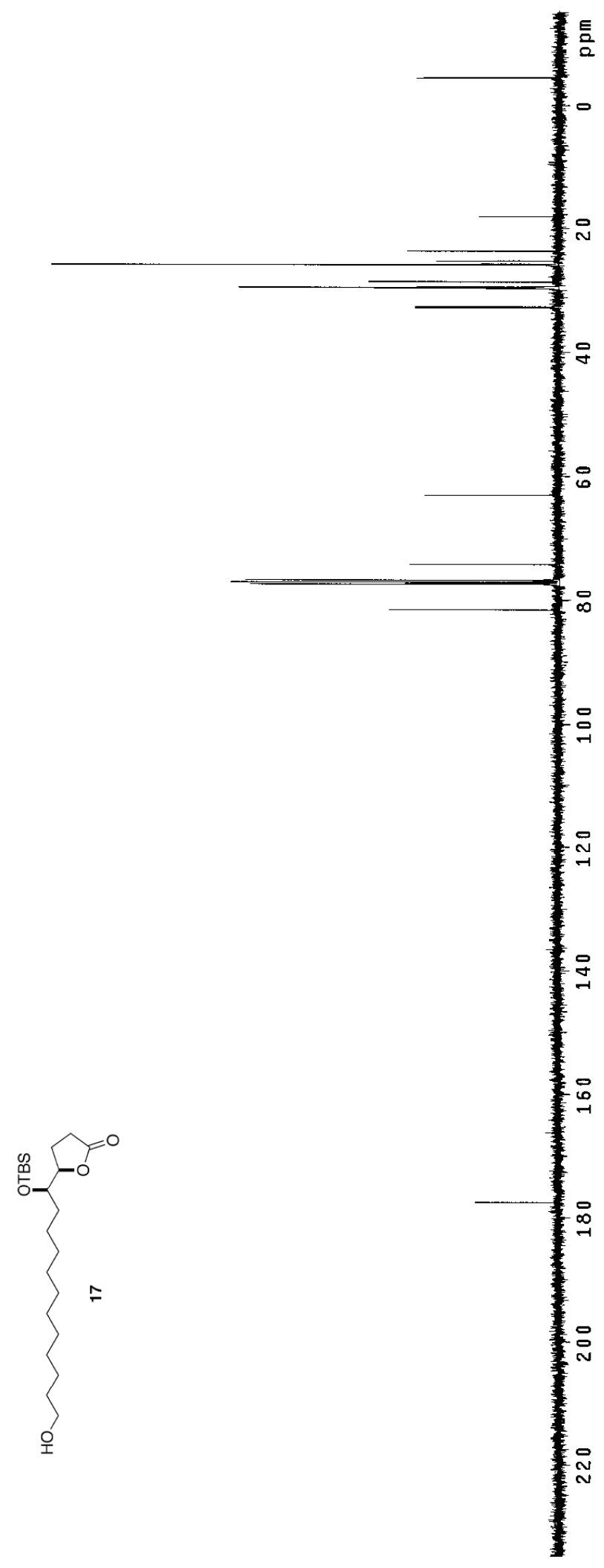




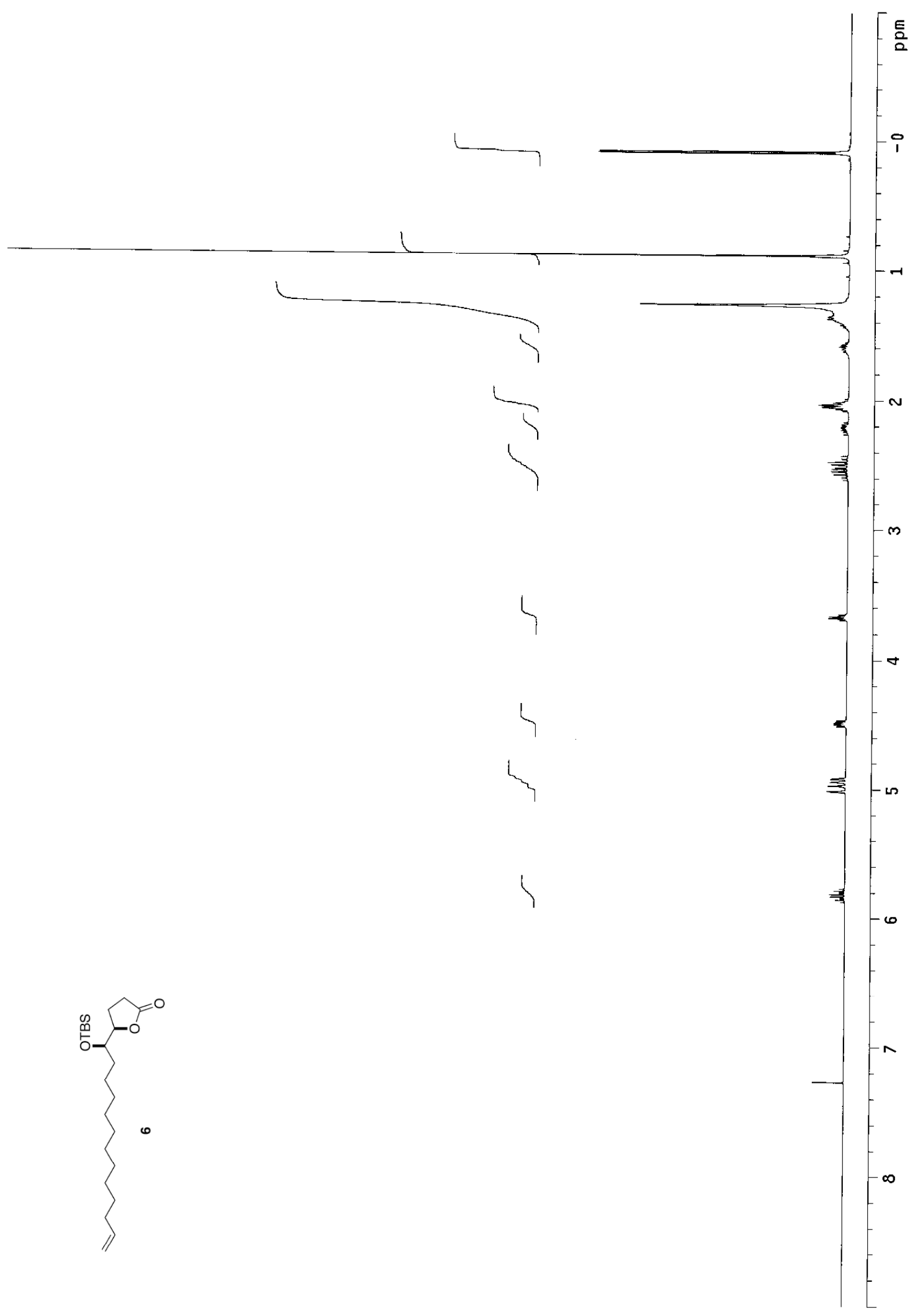




$$
\text { . }
$$




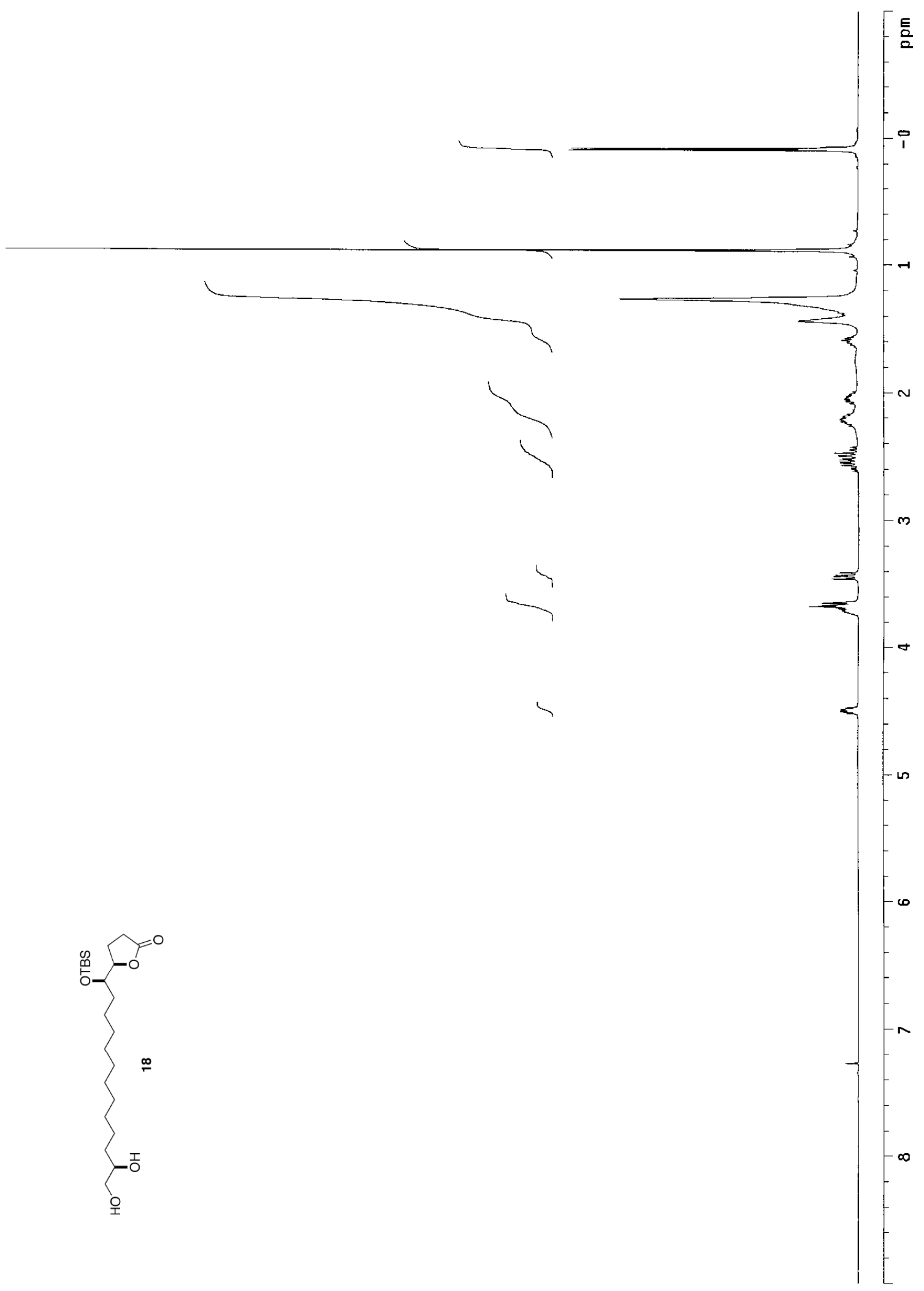




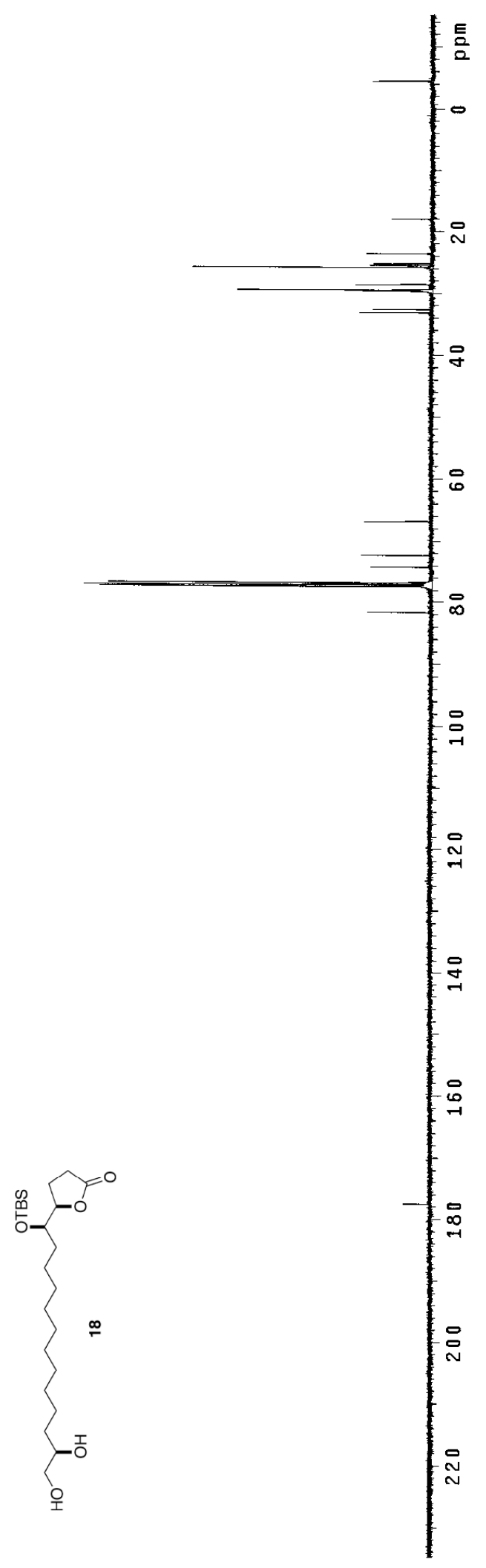




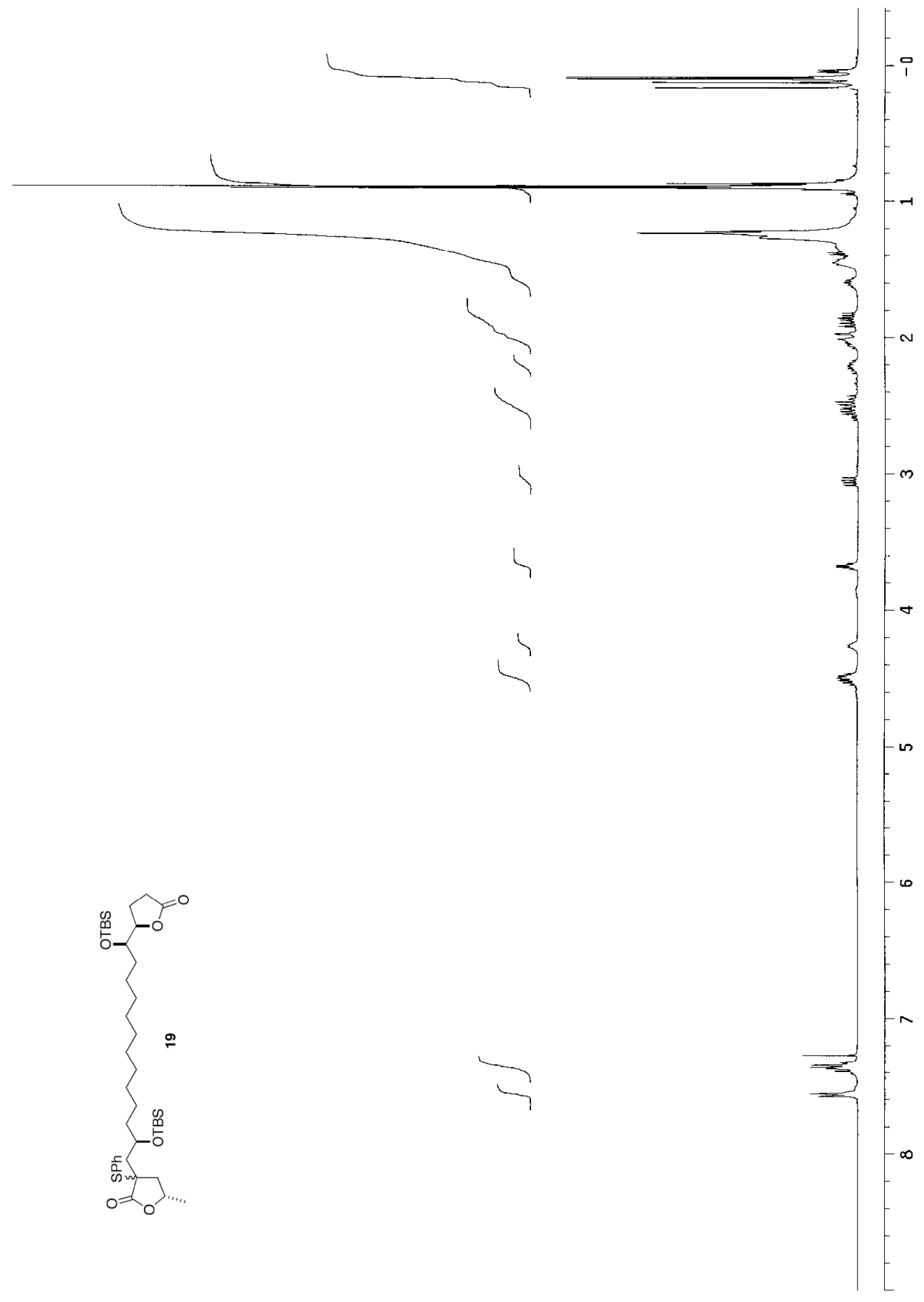




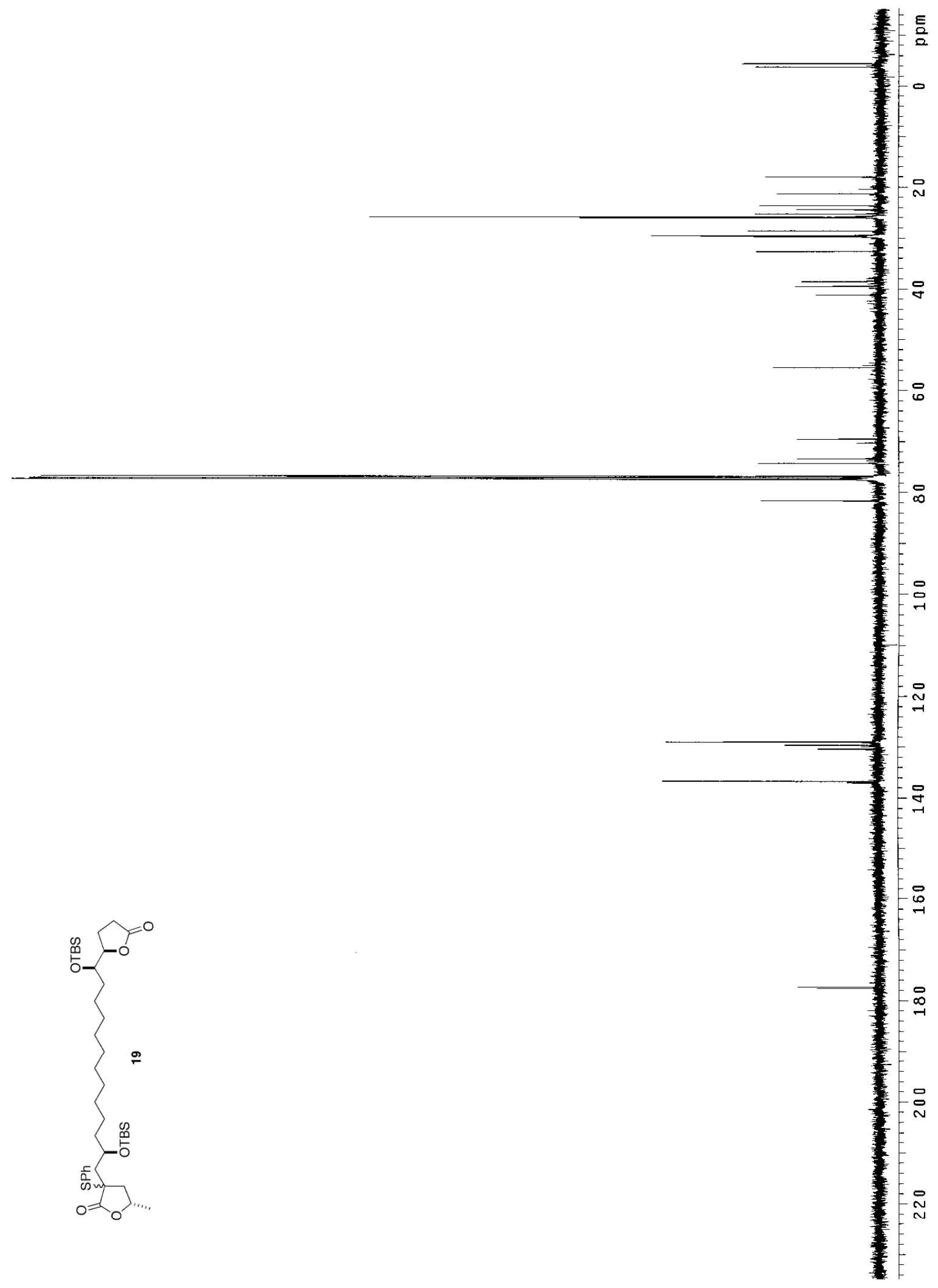




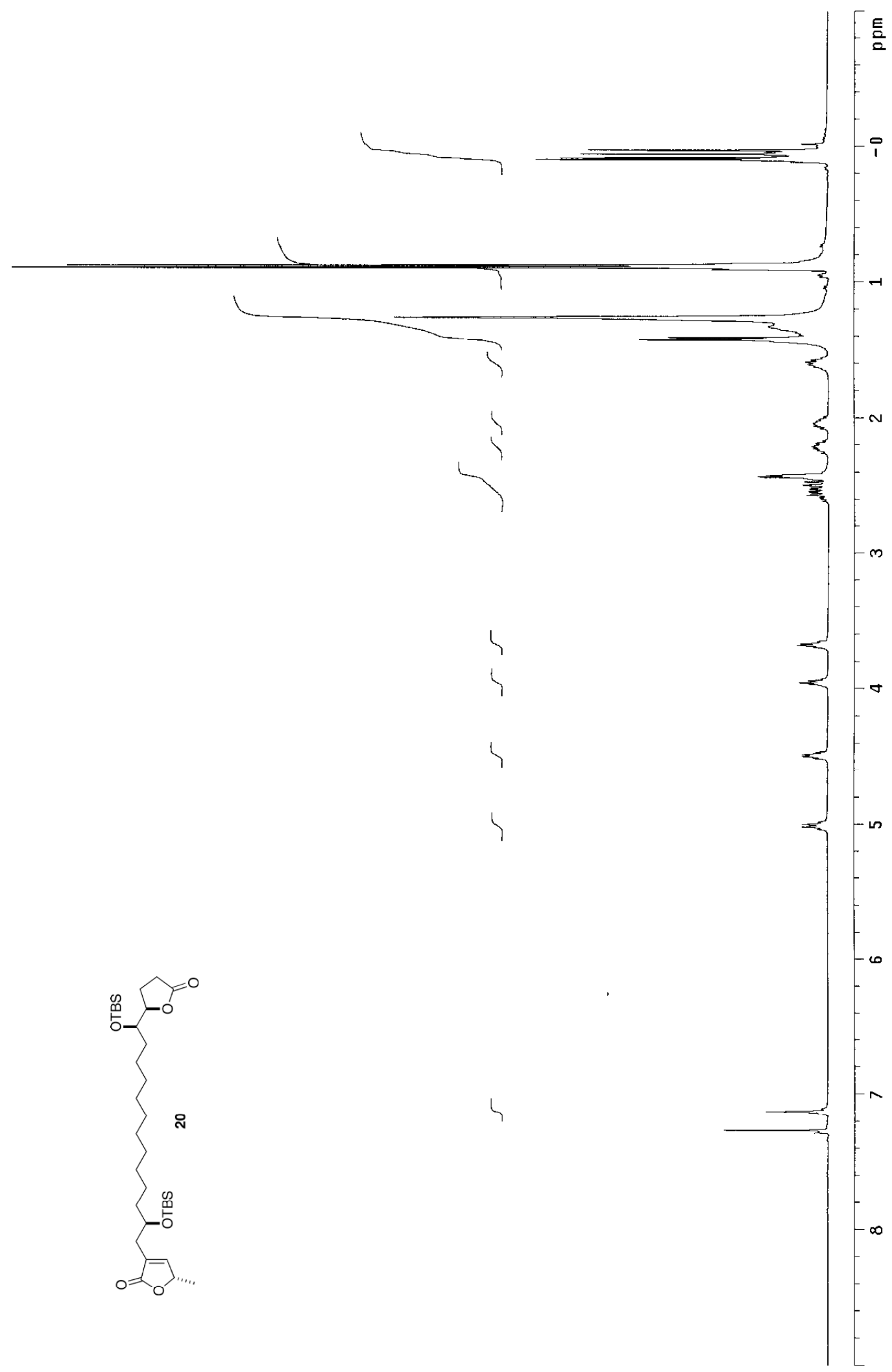




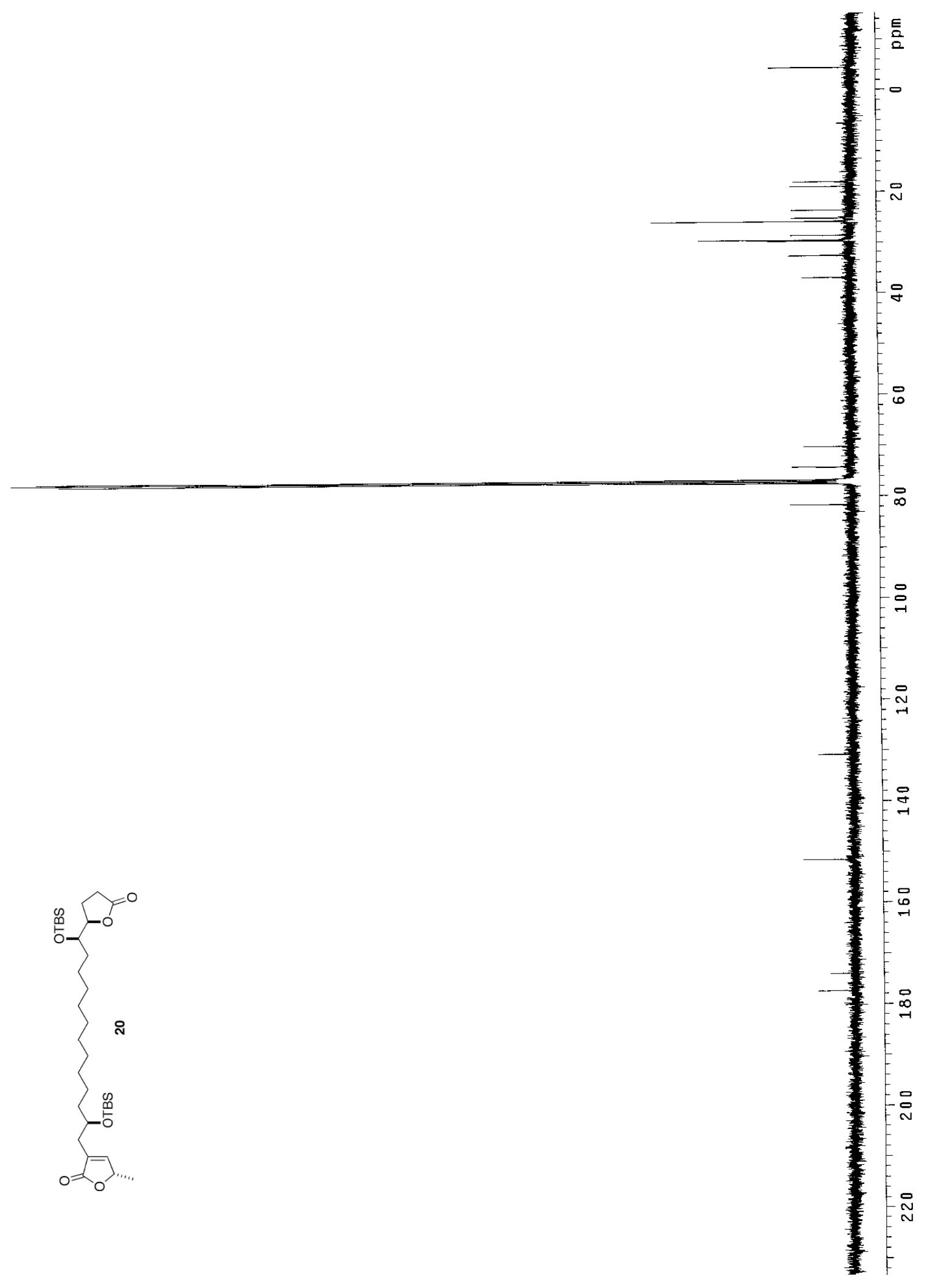




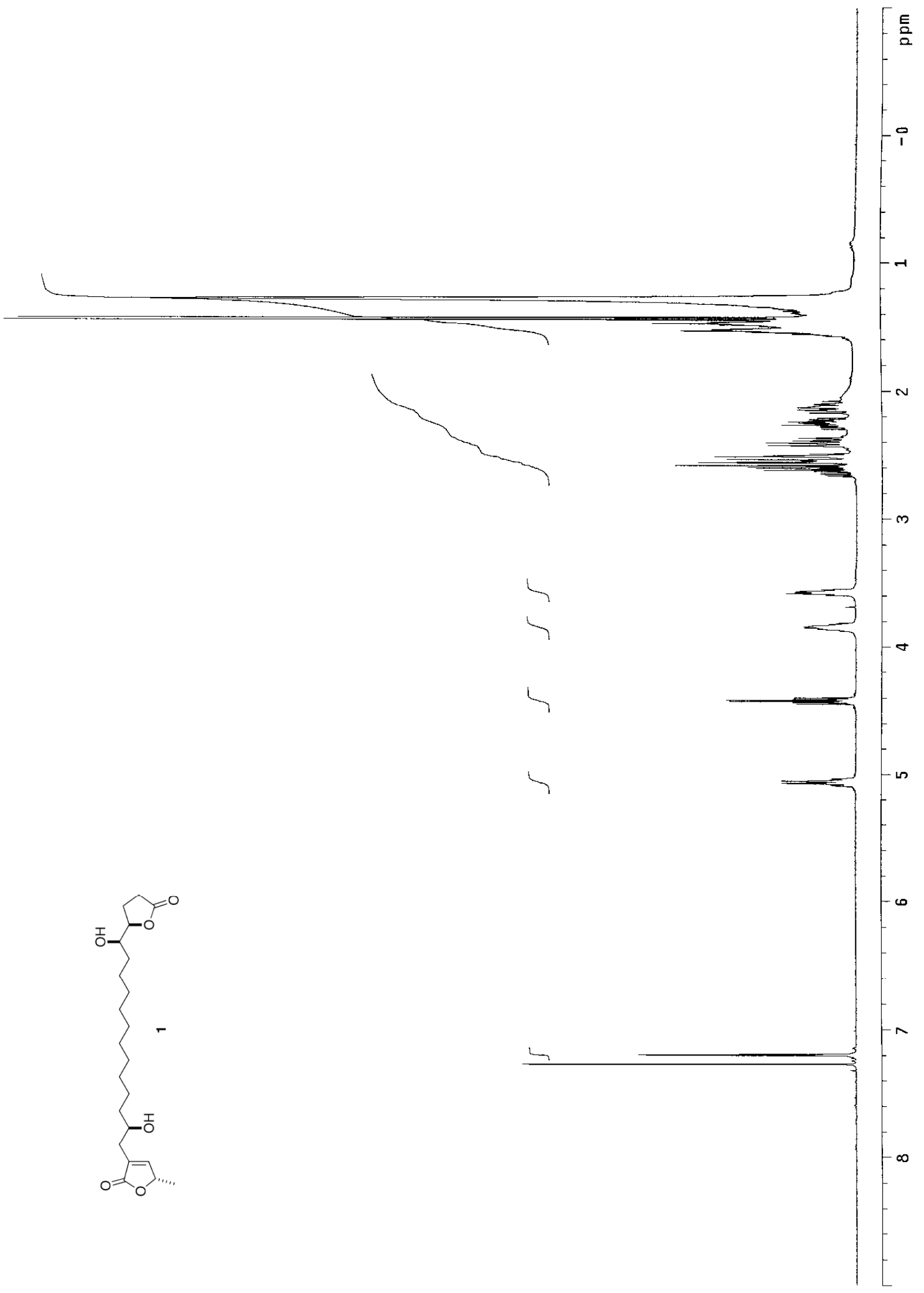




$$
4
$$

